\title{
ASSESS POTENTIAL FOR AGRITOURISM IN BACH DANG HAMLET, TAN UYEN TOWN, BINH DUONG PROVINCE
}

\author{
Ngô Hoàng Đại Long( ${ }^{(*)}$
}

\begin{abstract}
Agritourism has become popular in Vietnam, in which agriculture plays an important role in the economy and provides great condition for this tourism form. The development of agritourism, in turn, has benefited the agriculture, helping to enrich tourism services and improve the living conditions of local residents. This article presents a comprehensive assessment of potential for agritourism in Bach Dang hamlet, concluding that Bach Dang hamlet has valuable natural and cultural resources, and suitable policies for agritourism but lacks qualified human resource and sufficient tourism products to exploit this tourism form effectively.
\end{abstract}

Keywords: Potential, Agritourism, Bach Dang hamlet, Tourism products

Received date: June 11, 2016; Editing finished: January 10, 2017; Published: January 15, 2017

\section{1. Đặt vấn đề}

Du lịch nông thôn là một ý niệm chỉ hoạt động tham quan vùng quê hoặc đó là các quá trình sản xuất, kinh doanh từ nông thôn với mục đích nhận thức, sở thích, giáo dục hoặc nghỉ dưỡng, bao hàm trong đó cả tài nguyên nông thôn, tài nguyên tự nhiên và tài nguyên nhân văn [6]. Du lịch nông thôn giúp khai thác hiệu quả lợi thế du lịch và nông thôn dồi dào tại địa phương, tạo nguồn thu nhập thêm cho nông dân, kích thích sự đa dạng về các hoạt động kinh tế địa phương và tạo thêm nguồn thu ở khu vực nông thôn. Xã Bạch Đằng thuộc tỉnh Bình Dương là một trong những xã đầu tiên tiêu biểu của cả nước đã thực hiện xong chương trình nông thôn mới khi đạt 19 tiêu chí. Kết quả bước đầu cho thấy hoạt động nông thôn đã thực sự đem lại các hiệu quả kinh tế xã hội to lớn nhất là từ khi có sân Golf Mekong. Bài viết này đề cập đến việc đánh giá tổng hợp tiềm năng phát triển du lịch nông thôn xã Bạch Đằng, đặt nền tảng cho việc xây dựng các sản phẩm du lịch địa phương và phát triển hiệu quả mô hình du lịch nông thôn bền vững trong tương lai.

\section{Nội dung nghiên cứu}

\subsection{Tiềm năng phát triển du lịch nông thôn xã Bạch Đằng}

\subsubsection{Vị trí địa lí}

Bạch Đằng là một xã cù lao được bao bọc bởi sông Đồng Nai, nằm ở phía Đông của huyện Tân Uyên (Bình Dương), phía Bắc giáp với thị trấn Uyên Hưng (Bình Dương), phía Nam giáp với xã Tân Bình (Đồng Nai), phía Tây giáp với xã Khánh Bình (Tân Uyên, Bình Dương) một phần nhánh của sông Đồng Nai chạy dọc theo tỉnh lộ 747. Diện tích tự nhiên của xã là 1.075 ha, dân số 5.468 người với 1.346 hộ. Mặt khác, xã nằm gần các trung tâm đô thị lớn thuộc vùng Đông Nam Bộ, cách trung tâm kinh tế của cả nước. Cách trung tâm

(*) MA., University of Social Sciences and Humanities, VNU-HCM 
Uỷ ban nhân dân (UBND) thị xã Tân Uyên về phía Nam khoảng 2,5km; cách thành phố Thủ Dầu Một về phía Đông khoảng $8 \mathrm{~km}$; cách quốc lộ $13 \mathrm{khoảng} 6 \mathrm{~km}$; cách trung tâm thành phố Hồ Chí Minh khoảng 36 km; cách sân bay Tân Sơn Nhất khoảng 36 km; cách trung tâm thành phố Biên Hòa khoảng 9 km.

Đây là điều kiện quan trọng cho việc hình thành và phát triển các sản phẩm du lịch đa dạng với nhiều loại hình, dịch vụ để thu hút du khách trong nước và quốc tế đến với nơi đây.

\subsubsection{Tiềm năng về tự nhiên}

Địa hình: Bạch Đằng là xã cù lao nên địa hình mang đặc trưng của đồng bằng phù sa có hình cồn bãi (cù lao), nhìn trên bản đồ có dạng như chiếc "thuyền úp", ở giữa cao và thấp dần sang hai bên của sông Đồng Nai. Cảnh quan ở các dạng đồng bằng cù lao sông nước là điều kiện để phát triển nền nông thôn đa dạng, từ đó làm cơ sở để hình thành các loại hình du lịch sinh thái sông nước như du lịch vườn vườn cây ăn trái, du lịch tham quan cù lao.

Khí hậu: Các yếu tố của khí hậu ở Bạch Đằng như: chế độ bức xạ, nắng, nhiệt độ, độ ẩm, sức gió... nhìn chung khá phù hợp với sự phát triển du lịch nông thôn. Nhiệt độ không khí trung bình hàng năm cao và ổn định quanh năm cao. Biến thiên nhiệt độ giữa tháng nóng nhất và tháng lạnh nhất khoảng $3,3^{\circ} \mathrm{C}$. Tuy nhiên, biến thiên nhiệt độ ngày thì khá cao khoảng $10^{\circ} \mathrm{C}$. Nhiệt độ không khí trung bình năm: $26,7^{\circ} \mathrm{C}$ Nhiệt độ không khí bình quân tháng nóng nhất (tháng 4) là $28,4^{\circ} \mathrm{C}$ Nhiệt không khí bình quân tháng thấp nhất (tháng 11) là $25,1^{\circ} \mathrm{C}$. Lượng bức xạ tương đối lớn, tổng lượng nhiệt trong năm là $10.000^{\circ} \mathrm{C}$. Số giờ nắng Bạch Đằng dao động từ 100 đến gần 300 giờ nắng.

Trong năm có hai mùa rõ rệt là mùa mưa và mùa khô. Chế độ gió được đặc trưng bởi tác động luân phiên của hệ thống hoàn lưu gió mùa nên rất ổn định. Trong mùa khô thịnh hành gió mùa Đông Bắc kéo dài từ tháng 11 đến tháng 4 năm sau, thời tiết ít mưa, chỉ chiếm 10\% lượng mưa của cả năm. Vào mùa mưa, gió mùa Tây Nam mang khối khí biển nhiệt đới và xích đạo, lượng ẩm dồi dào, mưa nhiều, chiếm tới $90 \%$ lượng mưa cả năm, tập trung cao nhất vào tháng $7,8,9,10$. Với đặc điểm nằm sâu trong đất liền nên Bạch Đằng ít chịu ảnh hưởng của gió bão. Đây là điều kiện cơ bản để phát triển nền nông thôn đa dạng, ổn định, làm tiền đề cho việc xây dựng các hình thức du lịch dựa trên thế mạnh nông thôn nhiệt đới của xã. Căn cứ vào chỉ số sinh khí hậu đối với con người [2], các yếu tố khí hậu của xã Bạch Đằng cho thấy mức độ thích nghi và phù hợp cho việc phát triển các loại hình du lịch như du lịch tham quan, vui chơi, giải trí...

Thủy văn: Ở xã Bạch Đằng, nhờ hệ thống sông ngòi, kênh rạch phát triển, làm tiền đề cho việc hình thành và phát triển các loại hình du lịch liên quan đến sông nước như du lịch vườn cây ăn trái, du lịch sinh thái, du lịch văn hoá. Cù lao Bạch Đằng nằm ở vị trí Đoạn hạ lưu từ Tân Uyên ra đến biển dài $150 \mathrm{~km}$. Lòng sông rất rộng từ $0,1 \sim 4,5 \mathrm{~km}$ và độ sâu lớn nhất có nơi đạt $18 \mathrm{~m}$. Chính vì vậy mà cảng Sài Gòn tuy nằm sâu trong đất liền nhưng tàu cở lớn vẫn ra vào thuận lợi, đồng thời đoạn này cũng hình thành một vùng cửa sông vô cùng phức tạp, kênh rạch chằng chịt: Nhánh sông Đồng Nai - Soài Rạp; Nhánh sông Lòng Tàu thuộc sông Đồng Nai trên cơ bản chảy theo hai hướng chính: Phía Đông kinh tuyến $107^{0} Đ$ hướng Tây Bắc - Đông Nam là chủ yếu (phần thượng lưu); Phía Tây kinh tuyến $107^{\circ} Đ$ hướng Đông Bắc - Tây Nam chiếm ưu thế (chủ yếu là vùng trung và hạ lưu). 
Lưu vực sông Đồng Nai bao gồm khu tứ giác kinh tế (TGKT) trọng điểm phía Nam, với thành phố Hồ Chí Minh - Bình Dương - Biên Hòa - Vũng Tàu, có một tầm quan trọng đặc biệt trong chiến lược phát triển kinh tế xã hội của các tỉnh phía Nam nói riêng và cả nước nói chung, bởi tiềm năng kinh tế đa dạng và dồi dào, một nguồn nhân lực phong phú và năng động, lại nằm ở một vị trí địa lý vô cùng trọng yếu. Mùa nước nổi là một đặc trưng của toàn vùng, đồng thời cũng là thời điểm quan trọng cho việc khai thác thủy sản cũng như thực hiện kết hợp các tour du lịch nông thôn như: tham quan, tham gia sinh hoạt sản xuất cùng người dân địa phương...

Sinh vật: Bạch Đằng có hệ thống sinh vật đa dạng và phong phú với nhiều hệ động thực vật có giá trị khoa học. Các thảm thực vật tiêu biểu bao gồm: thảm thực vật đất ngập nước bưng trũng; thảm thực vật đồi núi; thảm thực vật ven sông rạch; thảm thực vật nổi. Hệ động thực vật phong phú sẽ tạo sức hút đối với du khách trong và ngoài nước, trên cơ sở đó có thể hình thành các điểm du lịch nông thôn.

Đất đai nơi đây phù hợp với phát triển các loại cây dài ngày như: điều, tiêu, và cây ăn trái như: bưởi, cam, chôm chôm, nhãn. Đặc biệt huyện có 9 loại bưởi, trong đó bưởi đường lá cam, bưởi thanh trà, bưởi ổi... ngon nổi tiếng. Để giống bưởi này mang lại giá trị kinh tế cao hơn nữa cho địa phương cần phải có phương án để xây dựng thương hiệu, quảng bá rộng rãi trong và ngoài nước cho sản phẩm bưởi có giá trị kinh tế cao.

\subsubsection{Tiềm năng về nhân văn}

Di tích lịch sử - văn hóa và danh thắng: Xã có các di tích lịch sử - văn hóa được xếp hạng cấp quốc gia, cấp tỉnh. Ngoài ra, xã còn có 5 di tích lịch sử - văn hóa chưa được công nhận nhưng có tiềm năng khai thác du lịch. Xã Bạch Đằng có 6 ấp: Bình Hưng, Tân Trạch, Điều Hòa, Tân Hòa, Tân Long, Tân An. Xã có 6 ngôi đình, 5 ngôi chùa, một tịnh xá trong đó đình Tân Trạch là di tích văn hóa cấp tỉnh. Ở Bạch Đằng còn có nhà cổ ông Đỗ Cao Thứa là di tích kiến trúc nghệ thuật cấp tỉnh. Đình, chùa, nhà cổ cũng là biểu tượng văn hóa, kiến trúc mà người dân Bạch Đằng luôn tự hào. Các hoạt động văn hóa thông tin, nghệ thuật, thể thao được tổ chức rộng khắp với nhiều loại hình thức và nội dung phong phú.

Các lễ hội sinh hoạt văn hóa và các đối tượng gắn liền với dân tộc học: Các điểm tập tục tín ngưỡng địa phương như: "Ngày 25 tháng chạp là lễ "Khép ấn" (hiểu nôm na là nghỉ việc để ăn tết!), sáng mùng một đầu năm mới, các bậc trưởng lão làm lễ mong một năm được mùa, bình yên. Tháng 4 âm lịch, làng tổ chức lễ 'Tống phong'. Lễ đền ơn đáp nghĩa anh hùng liệt sĩ hy sinh cho quê hương, đất nước được tổ chức vào 27-7 và lễ "Kỳ yên" vào tháng 10 (âm lịch)... Đó cũng là những ngày hội đại đoàn kết với nhiều hoạt động văn hóa dân gian như đua thuyền, thả vịt... Con cháu, dâu rể trong làng, ai đi xa cũng nhớ những ngày này để về thăm quê..." (Phỏng vấn cụ Nguyễn Văn Chính, sinh năm 1938, Trưởng ban quý tế của đình Bình Hưng).

Các làng nghề thủ công: Các làng nghề truyền thống là một yếu tố quan trọng trong việc xây dựng các tour tham quan kết hợp như tham quan sinh thái với làng nghề.

Văn hóa ẩm thực: Bạch Đằng có nhiều món ăn ngon mang đặc trưng ẩm thực vùng Nam Bộ. Cư dân của vùng đất này sáng tạo nhiều món đặc trưng góp phần làm giàu thêm cho văn hóa ẩm thực của vùng đất này gắn liền với bưởi như: gỏi bưởi, rượu bưởi, mật bưởi, chè bưởi... Đây cũng là một yếu tố quan trọng để thu hút khách du lịch. 


\subsubsection{Tiềm năng về sản xuất nông thôn}

Về trồng trọt: Tổng diện tích gieo trồng cây hàng năm là $600 / 600$ ha đạt $100 \%$ so kế hoạch năm và tăng 168 ha so cùng kỳ, gồm các loại cây trồng sau:

* Cây lúa: 570/570 ha, đạt 100\% so kế hoạch năm, tăng 168 ha so cùng kỳ. Trong đó: Vụ đông xuân: 190/190 ha, năng suất bình quân 6 tấn/ha; Vụ hè thu: 190/190 ha, năng suất bình quân 4 tấn/ha; Vụ mùa: 190/190ha, năng suất bình quân 4,6 tấn/ha.

* Cây rau: 30/30 ha đạt 100\% kế họach năm.

Tình hình sâu bệnh tuy có phát sinh nhưng nông dân đã chủ động phòng trừ kịp thời nên không ảnh hưởng lớn đến cây trồng.

* Cây lâu năm (cây bưởi) 386 ha.

* Tổng sản lượng lương thực cả năm đạt 2.774 tấn đạt 100\% kế hoạch (tăng 892 tấn so năm 2013), bình quân lương thực đầu người $454 \mathrm{~kg} /$ năm đạt $100 \%$ kế hoạch (tăng 136 kg/người/năm so năm 2013).

Thực hiện 100 ha vườn bưởi đặc sản, tổ chức cung cấp vật tư phân bón được $247 / 276$ hộ, diện tích $54,70 / 71$ ha đạt $78 \%$. Đồng thời, tổ chức vận động trồng mới cây bưởi được 100 hộ với diện tích 23,90 ha. Trong năm 2013 có 162 hộ dân tham gia thực hiện trồng mới và chăm sóc bưởi đường lá cam (trong đó: trồng mới là 97 hộ, với diện tích $180.602 \mathrm{~m}^{2}$ và chăm sóc là 65 hộ, với diện tích $\left.150.710 \mathrm{~m}^{2}\right)^{(1)}$.

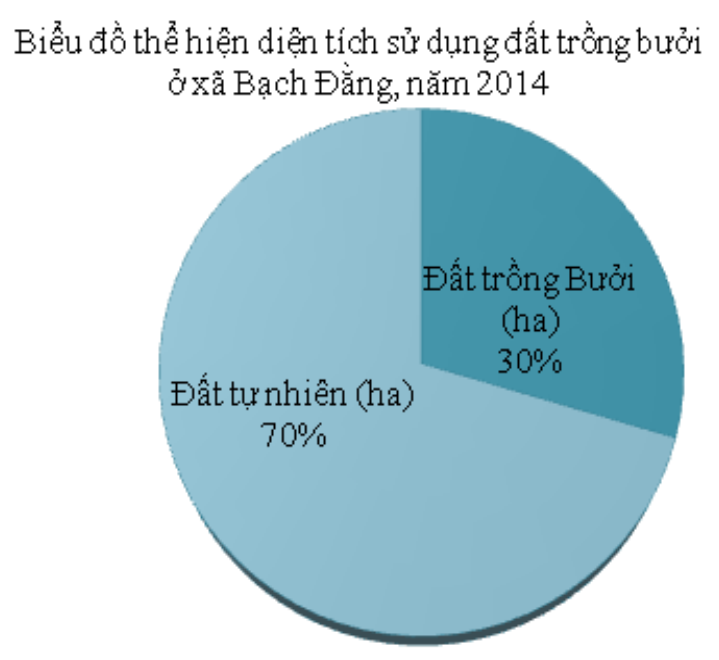

Ngoài ra, trong năm 2014 có 298 hộ dân đã thực hiện đăng ký trồng mới và chăm sóc các giống bưởi đường lá và bưởi ổi, có 125 hộ trồng mới với diện tích $243.953 \mathrm{~m}^{2}$, (trong đó bưởi đường lá cam: 124 hộ, với diện tích $242.453 \mathrm{~m}^{2}$, bưởi ổi: 01 hộ, với diện tích $1.500 \mathrm{~m}^{2}$, chăm sóc: 173 hộ, với diện tích $\left.384.438 \mathrm{~m}^{2}\right)^{(2)}$. Hiện nay, nhãn hiệu bưởi Bạch Đằng ${ }^{(3)}$ đã thu hút được 14 hộ trồng bưởi của địa phương tham gia. Số lượng thành viên sẽ được nâng lên trong thời gian tới và NHTT bưởi Bạch Đằng được kỳ vọng sẽ giúp họ nâng cao giá trị gia tăng từ nghề trồng bưởi truyền thống. 


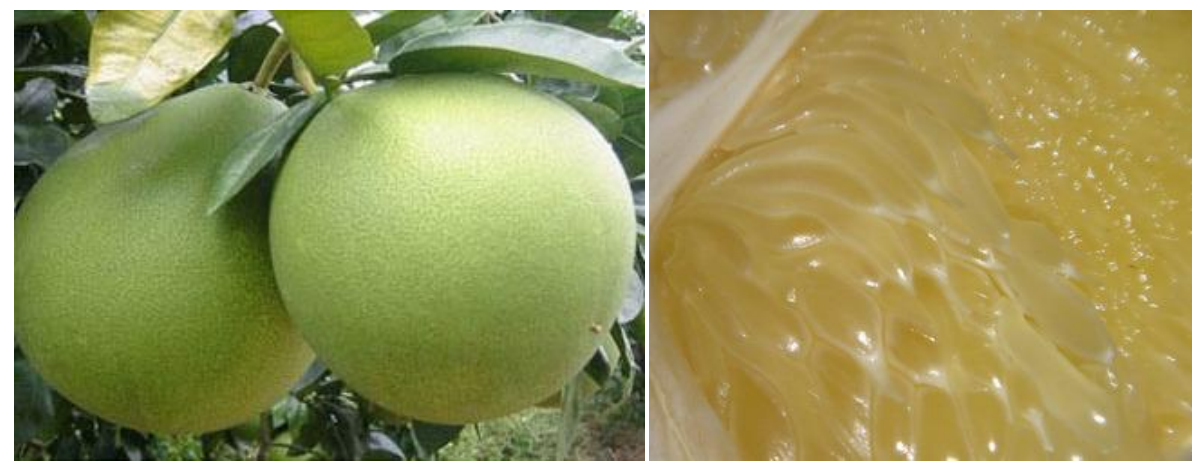

Ảnh. Bưởi Bạch Đằng, tác giả chụp 2016

Về chăn nuôi: Tổng đàn trâu bò toàn xã là 425 con, tăng 15 con so cùng kỳ, đàn heo 259 con, tăng 36 con so cùng kỳ. Tổ chức tiêm phòng cúm gia cầm 02 đợt được 18.835 con/19.200 con đạt $98 \%$.

Về công tác khuyến nông: Phối hợp Trạm Bảo vệ thực vật thị xã tổ chức tập huấn KHKT trên cây lúa, cây rau, cây bưởi được 12 cuộc/568 lượt người dự. Phối hợp Chi cục BVTV tỉnh lắp đặt 12 hố chứa rác thải nông nghiệp (nâng tổng số đến nay là 16 hố chứa rác thải nông nghiệp).

Cơ cấu cây trồng: Tổ chức thực hiện Quyết định số 45/2012 của UBND tỉnh về hỗ trợ phát triển vườn cây đặc sản truyền thống của xã, kết quả đăng ký đến nay diện tích trồng mới được 42,45 ha/222 hộ, vườn bưởi chăm sóc được 20,38 ha/76 hộ. UBND xã phối hợp với phòng Kinh tế đã cấp tiền cây giống, tiền công chăm sóc, phân bón và thuốc bảo vệ thực vật các loại năm 2014 cho các hộ dân tham gia dự án với tổng số tiền là 633.522 .100 đồng.

Trên cơ sở khai thác các thế mạnh về nông thôn, nhiều sản phẩm du lịch được tạo ra từ sản xuất nông thôn có sức thu hút khách du lịch trong và ngoài nước. Các loại hình du lịch sinh thái, các tour tham quan mô hình hợp tác xã (HTX), miệt vườn, tham gia sản xuất cùng nông dân, tổ chức chài lưới bắt cá, dịch vụ homestay... được đầu tư phát triển và ngày càng hấp dẫn du khách.

Nhìn chung, sự phát triển mạnh về nông thôn mới và sản xuất nông nghiệp từ bưởi của xã Bạch Đằng đã tạo ra những tiền đề quan trọng để xây dựng các loại hình du lịch nông thôn đa dạng. Việc phát triển nông thôn gắn liền với hoạt động du lịch có tác động to lớn trong việc phát huy thế mạnh, nâng cao thu nhập, đa dạng hóa cơ cấu sản xuất, góp phần thúc đẩy kinh tế xã hội của xã phát triển bền vững.

\subsubsection{Bước khởi đầu và những thành tựu đạt được từ phát triển du lịch nông thôn}

Dựa trên cơ sở về tiềm năng du lịch nông thôn, xã Bạch Đằng bước đầu đã thu hút các nhà đầu tư nước ngoài áp dụng hình thức du lịch mới và đạt được những thành tựu cơ bản. Đánh giá sơ bộ ban đầu cù lao xã Bạch Đằng hội tủ các yếu tố về môi trường và điều kiện kinh tế xã hội phục vụ cho việc phát triển du lịch nhất là các loại hình du lịch cộng đồng, du lịch vườn cây ăn trái kết hợp, du lịch sông nước, du lịch homestay... đặc biệt nếu tổ chức bài bản và chặt chẽ thì nơi đây vẫn hội tụ đầy đủ các yếu tố cho việc tổ chức và thực hiện các hoạt động du lịch sinh thái miệt vườn. 
Điều đặc biệt là các nhà vườn nơi đây với thế mạnh chủ lực là cây bưởi được truyền lại qua nhiều thế hệ qua các phương thức và kinh nghiệm trồng trọt độc đáo, các cư dân nơi đây có lịch sử hiếu học truyền thống lâu đời, văn hóa địa phương sâu sắc. Đó là những thế mạnh nếu khai thác tốt kết hợp với du lịch thì cù lao Bạch Đằng sẽ là một điểm đến hấp dẫn trong và ngoài nước.

\subsubsection{Việc đầu tư du lịch cho phát triển nông thôn}

Thương mại, dịch vụ: Thực hiện địa bàn khu du lịch sinh thái, đến nay đã tổ chức giao quyết định bồi thường hỗ trợ tái định cư địa bàn khu du lịch sinh thái được 244/244 hộ đạt $100 \%$. Công tác chi trả tiền đền bù được 239/281 hộ nhận tiền đền bù đạt $85,05 \%$. Tổ chức thực hiện công tác kê biên bắt buộc 8 hộ chưa thực hiện địa bàn khu du lịch sinh thái. Chi trả hỗ trợ hoa màu những hộ thuê đất công ích được 68 hộ.

Du lịch, các tuyến liên kết: Vườn bưởi của các thành viên trong Tổ hợp tác bưởi Bạch Đằng cũng thu hút nhiều du khách đến tham quan, thưởng thức đặc sản. Riêng năm 2014 tổ đã liên kết với Công ty Du lịch - nghỉ dưỡng Mắt Xanh đón 7 đoàn khách gồm 750 người ${ }^{(4)}$ đến tham quan du lịch tại các vườn bưởi.

Các khu du lịch (KDL) bao gồm các điểm liên kết chính sau: Khu du lịch sinh thái Hàn Tam Đẳng - Tân Định; Khu du lịch sinh thái cuả công ty trách hiệm hữu hạn $(\mathrm{TNHH})$ Vân Thịnh - xã Tân Định; Khu du lịch sinh thái nghỉ dưỡng Mắt Xanh - Tân Định; Khu du lịch sinh thái nghỉ dưỡng Cù lao Thạnh Hội; Khu du lịch Hồ Đá Bàn - Đất Cuốc; Khu du lịch Mê Kông Golf và Villas Bạch Đằng.

Tuyến du lịch dọc sông Đồng Nai dài $90 \mathrm{~km}$ gồm các điểm chính sau: Cù Lao Rùa (vùng vườn); Làng nghề gồm Tân Phước Khánh; Và điểm du lịch, văn hóa cảnh quan 11 ha với đình làng Tân Phước Khánh; Hồ Đá Bàn; Vùng rừng Chiến khu $\mathrm{D}$.

\section{2. Đánh giá chung về tiềm năng và hướng phát triển du lịch nông thôn xã Bạch Đằng}

\subsubsection{Các điểm du lịch được lựa chọn đánh giá tiềm năng du lịch nông thôn}

Hộ nhà vườn trồng bưởi (chú Bảy Hùng): Bình Dương nổi tiếng với hương vị ngọt thanh, tép màu vàng nhạt, bó chặt, dễ tách khỏi múi, có mùi thơm dịu, vị ngọt không chua, không the ở môi, không đắng ở miệng. Bưởi Bạch Đằng (Bảy Hùng) được trồng và bảo quản sau thu hoạch theo mô hình khép kín theo tiêu chuẩn VietGAP(5), không sử dụng phân bón hóa học và hóa chất bảo quản, đảm bảo sản phẩm đầu ra sạch tuyệt đối và có chất lượng đồng đều khi tới tay khách hàng.

Sân Golf Mekong: sân Golf Mê kông trải rộng trên diện tích 200 ha, tọa lạc tại Cù lao Bạch Đằng thơ mộng với 54 lỗ golf, hiện tại đã hoàn thành 18 lỗ. Trong tương lai, nơi đây sẽ phục vụ du khách đến thư giãn thể thao và phục vụ các giải thi đấu quốc tế.

Đình Tân Trạch và các đình khác như: (Bình Hưng, Điều Hòa, Tân Hòa, Tân Long, Tân An)

Các ngôi chùa trên cù lao Bạch Đằng: nơi tập trung các tín ngưỡng tâm linh của người dân xứ cù lao. 
Nhà cổ Đỗ Cao Thứa: ngôi nhà cổ Đỗ Cao Thứa được xây dựng khoảng cuối thế kỷ XIX uy nghi lộng lẫy theo lối kiến trúc chữ Đinh, mái lợp ngói âm dương dày, trầm mặc cổ kính, rộng lớn bề thế được làm toàn bằng gỗ quý kiên cố với những nét hoa văn chạm trổ công phu tinh xảo. Ngoài ra còn có những bao lam, hoành phi, liễn, đại tự, khánh thờ được trang trí hoa văn cách điệu, chủ đề: long, lân, quy, phụng, nai, điểu, nho, sóc... đã tạo nên những nét văn hóa nghệ thuật độc đáo do đôi bàn tay khéo léo của những nghệ nhân chạm khắc tài hoa tạo nên, mang đậm phong cách văn hóa Việt trên đất Bình Dương thời bấy giờ. Ngôi nhà được xây dựng trong một khu vườn thoáng mát, cảnh quan tuyệt đẹp trong một màu xanh của cây trái sum suê đón gió lành, mát mẻ quanh năm.

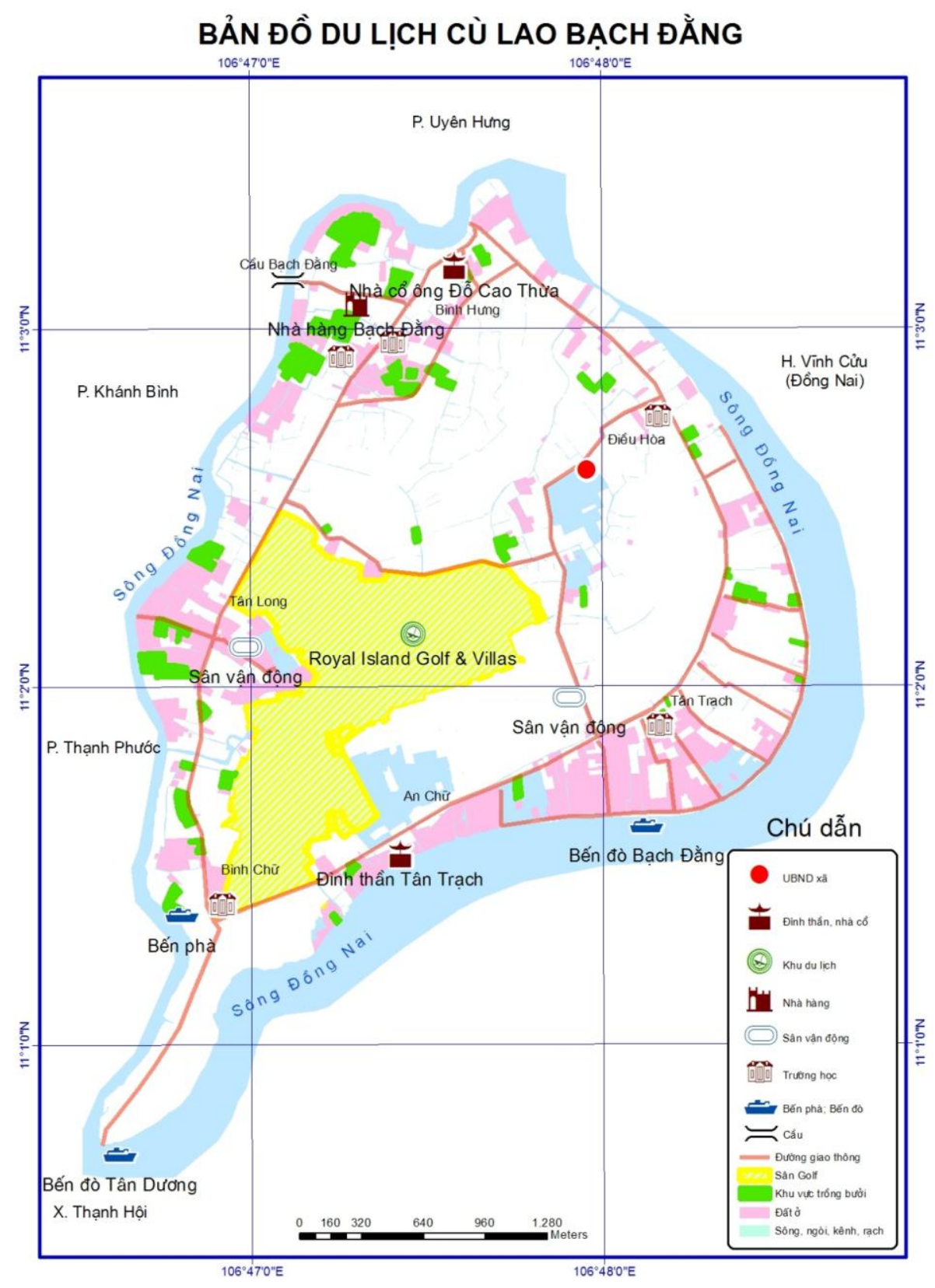

Nguồn: do tác giả thực hiện 2016 


\subsubsection{Chọn tiêu chí đánh giá và hệ số của các tiêu chí}

Các điểm du lịch ở xã Bạch Đằng được đánh giá định lượng dựa trên phương pháp thang điểm tổng hợp có trọng số của Viện Nghiên cứu phát triển du lịch Việt Nam (VNCPTDLVN). Các tiêu chí được lựa chọn để đánh giá dựa vào thang điểm tổng hợp được xây dựng bởi VNCPTDLVN và các điều kiện tiên quyết phát triển du lịch sinh thái cộng đồng (DLSTCĐ) được xây dựng bởi Quỹ Quốc tế Bảo vệ Thiên nhiên.

Tuy nhiên, mục tiêu chính là đánh giá tiềm năng đối với các điểm du lịch nông thôn dựa vào cộng đồng nên nhóm tác giả đã đưa thêm một số tiêu chí quan trọng như: mức độ hấp dẫn về văn hoá cộng đồng; đồng thời bỏ đi một số tiêu chí hướng đến hiệu quả khai thác như: cơ sở hạ tầng - cơ sở kỹ thuật du lịch, hiệu quả kinh tế địa phương.

Các trọng số của các tiêu chí đựa thừa kế từ nghiên cứu của VNCPTDLVN, riêng tiêu chí mức độ bền vững về tự nhiên được nâng lên thành hệ số 2 (thay vì hệ số 1 ), vì bảo tồn hệ sinh thái vườn là một trong những tiêu chí được chú trọng trong DLSTCĐ. Các tiêu chí và hệ số của các tiêu chí được lựa chọn đánh giá được mô tả ở bảng bên dưới:

Bảng 1. Điểm đánh giá tổng hợp các tiêu chí điểm du lịch

\begin{tabular}{|l|l|c|}
\hline STT & Tiêu chí & Trọng số \\
\hline 1 & Độ hấp dẫn về cảnh quan du lịch & 3 \\
\hline 2 & Mức độ hấp dẫn về văn hoá cộng đồng & 3 \\
\hline 3 & Vị trí điểm du lịch & 3 \\
\hline 4 & Thời gian hoạt động du lịch & 3 \\
\hline 5 & Sức chứa khách du lịch & 2 \\
\hline 6 & Tính liên kết & 2 \\
\hline 7 & Khả năng tiếp cận điểm du lịch & 2 \\
\hline 8 & Mức độ bền vững về hệ sinh thái tự nhiên & 2 \\
\hline 9 & Mức độ bền vững về văn hoá cộng đồng & 2 \\
\hline 10 & Mức độ an toàn về mặt xã hội & \\
\hline & Tổng số điểm & 2 \\
\hline
\end{tabular}

Nguồn: do tác giả tính toán 2016

\subsubsection{Chọn chỉ tiêu cho các cấp đánh giá}

Điểm đánh giá tổng hợp của các tiêu chí theo 4 cấp đánh giá ở mỗi tiêu chí, tương với các mức độ (rất thuận lợi, thuận lợi, ít thuận lợi, kém thuận lợi) về tiềm năng của các điểm du lịch (bảng bên dưới). Việc xây dựng và lựa chọn các chỉ tiêu của các cấp độ này dựa vào nghiên cứu của tác giả Bùi Thị Hải Yến (2010) và điều kiện thực tế của khu vực nghiên cứu. 
Bảng 2. Điểm đánh giá tổng hợp các tiêu chí điểm du lịch

\begin{tabular}{|c|c|c|c|}
\hline STT & Tiêu chí & Cấp độ & Chỉ tiêu \\
\hline \multirow{4}{*}{1} & \multirow{4}{*}{$\begin{array}{l}\text { Độ hấp dẫn về } \\
\text { cảnh quan du } \\
\text { lịch }\end{array}$} & $\begin{array}{l}\text { Rất hấp } \\
\text { dẫn }\end{array}$ & $\begin{array}{l}\text { Cảnh quan đẹp, tự nhiên còn nguyên sơ của đồng } \\
\text { quê }\end{array}$ \\
\hline & & $\begin{array}{l}\text { Khá hấp } \\
\text { dẫn }\end{array}$ & Cảnh quan đẹp, tự nhiên còn tương đối \\
\hline & & $\begin{array}{l}\text { Trung } \\
\text { bình }\end{array}$ & Cảnh quan tương đối đẹp, tính tự nhiên không cao \\
\hline & & $\begin{array}{l}\text { Kém hấp } \\
\text { dẫn }\end{array}$ & Cảnh quan đơn điệu, tính tự nhiên kém \\
\hline \multirow{4}{*}{2} & \multirow{4}{*}{$\begin{array}{l}\text { Mức độ hấp dẫn } \\
\text { về văn hoá cộng } \\
\text { đồng }\end{array}$} & $\begin{array}{l}\text { Rất hấp } \\
\text { dẫn }\end{array}$ & $\begin{array}{l}\text { Cộng đồng còn lưu giữ nhiều bản sắc văn hoá } \\
\text { truyền thống trên } 300 \text { năm }\end{array}$ \\
\hline & & $\begin{array}{l}\text { Khá hấp } \\
\text { dẫn }\end{array}$ & $\begin{array}{l}\text { Cộng đồng còn lưu giữ nhiều bản sắc văn hoá } \\
\text { truyền thống khoàng } 100 \text { năm }\end{array}$ \\
\hline & & $\begin{array}{l}\text { Trung } \\
\text { bình }\end{array}$ & $\begin{array}{l}\text { Cộng đồng còn lưu giữ một vài nét về giá trị văn hoá } \\
\text { truyền thống }\end{array}$ \\
\hline & & $\begin{array}{l}\text { Kém hấp } \\
\text { dẫn }\end{array}$ & $\begin{array}{l}\text { Cộng đồng không còn lưu giữ nét văn hoá truyền } \\
\text { thống }\end{array}$ \\
\hline \multirow{4}{*}{3} & \multirow{4}{*}{$\begin{array}{l}\text { Vị trí điểm du } \\
\text { lịch }\end{array}$} & Rất gần & Cách Trung tâm Thị xã < 10 km \\
\hline & & Khá gần & Cách Trung tâm Thị xã < 10 km \\
\hline & & $\begin{array}{l}\text { Trung } \\
\text { bình }\end{array}$ & Cách Trung tâm Thị xã < 10 km \\
\hline & & $\mathrm{Xa}$ & Cách Trung tâm Thị xã < 10 km \\
\hline \multirow{3}{*}{4} & \multirow{3}{*}{$\begin{array}{l}\text { Thời gian hoạt } \\
\text { động du lịch }\end{array}$} & Rất dài & $\begin{array}{l}\text { Có > } 200 \text { ngày trong năm có thể triển khai tốt các } \\
\text { hoạt động du lịch và > } 180 \text { ngày trong năm có điều } \\
\text { kiện khí hậu thích hợp nhất đối với sức khỏe con } \\
\text { người. }\end{array}$ \\
\hline & & Khá dài & $\begin{array}{l}\text { Có } 150 \text { - } 200 \text { ngày trong năm có thể triển khai tốt } \\
\text { các hoạt động du lịch và từ } 120 \text { - } 180 \text { ngày trong } \\
\text { năm có điều kiện khí hậu thích hợp nhất đối với sức } \\
\text { khỏe con người. }\end{array}$ \\
\hline & & $\begin{array}{l}\text { Trung } \\
\text { bình }\end{array}$ & $\begin{array}{l}\text { Có } 100 \text { - } 150 \text { ngày trong năm có thể triển khai tốt } \\
\text { các hoạt động du lịch và từ } 90 \text { - } 120 \text { ngày trong năm } \\
\text { có điều kiện khí hậu thích hợp nhất đối với sức khỏe } \\
\text { con người. }\end{array}$ \\
\hline
\end{tabular}




\begin{tabular}{|c|c|c|c|}
\hline & & Ngắn & $\begin{array}{l}\text { Có < } 100 \text { ngày trong năm có thể triển khai tốt các } \\
\text { hoạt động du lịch và < } 90 \text { ngày trong năm có điều } \\
\text { kiện khí hậu thích hợp nhất đối với sức khỏe con } \\
\text { người. }\end{array}$ \\
\hline \multirow[b]{3}{*}{5} & \multirow{4}{*}{$\begin{array}{l}\text { Sức chứa khách } \\
\text { du lịch }\end{array}$} & Rất lớn & > 200 người/ngày \\
\hline & & Khá lớn & > 100 - 200 người/ngày \\
\hline & & $\begin{array}{l}\text { Trung } \\
\text { bình }\end{array}$ & > 50 - 100 người/ngày \\
\hline & & Nhỏ & $>50$ người/ngày \\
\hline \multirow{4}{*}{6} & \multirow{4}{*}{ Tính liên kết } & Rất tốt & Có trên 3 điểm TNDL khác trong bán kinh 10 km \\
\hline & & Khá tốt & Có từ 2-3 điểm TNDL khác trong bán kinh 10 km \\
\hline & & $\begin{array}{l}\text { Trung } \\
\text { bình }\end{array}$ & Có trên 1 điểm TNDL khác trong bán kinh 10 km \\
\hline & & Kém & Không có điểm TNDL khác trong bán kinh 10 km \\
\hline \multirow{4}{*}{7} & \multirow{4}{*}{$\begin{array}{l}\text { Khả năng tiếp } \\
\text { cận điểm du lịch }\end{array}$} & $\begin{array}{l}\text { Dễ } \text { tiếp } \\
\text { cận }\end{array}$ & $\begin{array}{l}\text { Có đường đi thuận tiện, dễ dàng tiếp cận với điểm } \\
\text { du lịch }\end{array}$ \\
\hline & & $\begin{array}{l}\text { Khá tiếp } \\
\text { cận }\end{array}$ & Có đường đi thuận tiện, dễ tìm đường tương đối \\
\hline & & $\begin{array}{l}\text { Trung } \\
\text { bình }\end{array}$ & $\begin{array}{l}\text { Có đường đi thuận tiện, dễ tìm đường tương đối, } \\
\text { việc tìm đường đôi lúc dễ lạc, cần có người chỉ dẫn }\end{array}$ \\
\hline & & $\begin{array}{l}\text { Khó tiếp } \\
\text { cận }\end{array}$ & Chưa có đường đi thuận tiện, tìm đường khó khăn \\
\hline \multirow{4}{*}{8} & \multirow{4}{*}{$\begin{array}{l}\text { Mức độ bền } \\
\text { vững về tự } \\
\text { nhiên }\end{array}$} & $\begin{array}{l}\text { Rất bền } \\
\text { vững }\end{array}$ & $\begin{array}{l}\text { Trong năm năm gần đây không có thành phần hoặc } \\
\text { bộ phận tự nhiên nào bị tổn hại }\end{array}$ \\
\hline & & $\begin{array}{l}\text { Khá bền } \\
\text { vững }\end{array}$ & $\begin{array}{l}\text { Trong năm năm gần đây không có thành phần hoặc } \\
\text { bộ phận tự nhiên nào bị tổn hại nhưng ở mức độ nhẹ } \\
\text { có thể tự phục hồi }\end{array}$ \\
\hline & & $\begin{array}{l}\text { Trung } \\
\text { bình }\end{array}$ & $\begin{array}{l}\text { Trong năm năm gần đây không có thành phần hoặc } \\
\text { bộ phận tự nhiên nào bị tổn hại nhưng ở mức độ nhẹ } \\
\text { có thể tự phục hồi nhờ con người }\end{array}$ \\
\hline & & $\begin{array}{l}\text { Kém bền } \\
\text { vững }\end{array}$ & $\begin{array}{l}\text { Trong năm năm gần đây không có thành phần hoặc } \\
\text { bộ phận tự nhiên nào bị tổn hại nhưng khó có thể tự } \\
\text { phục hồi hoặc phục hồi phải mất thời gian dài }\end{array}$ \\
\hline 9 & $\begin{array}{lll}\text { Mức } & \text { độ } & \text { bền } \\
\text { vững } & \text { về } & \text { văn }\end{array}$ & $\begin{array}{l}\text { Rất bền } \\
\text { vững }\end{array}$ & $\begin{array}{l}\text { Nền văn hoá được cộng đồng giữ gìn và phát huy rất } \\
\text { tốt }\end{array}$ \\
\hline
\end{tabular}




\begin{tabular}{|c|c|c|c|}
\hline & \multirow[t]{3}{*}{ hoá cộng đồng } & $\begin{array}{l}\text { Khá bền } \\
\text { vững }\end{array}$ & Phần lớn nền văn hoá được cộng đồng giữ gìn \\
\hline & & $\begin{array}{l}\text { Trung } \\
\text { bình }\end{array}$ & Nền văn hoá được cộng đồng có nguy cơ bị mai mốt \\
\hline & & $\begin{array}{l}\text { Kém bền } \\
\text { vững }\end{array}$ & Nhiều yếu tố văn hoá đã dần mất đi \\
\hline \multirow{4}{*}{10} & \multirow{4}{*}{$\begin{array}{l}\text { Mức độ an toàn } \\
\text { về mặt xã hội }\end{array}$} & $\begin{array}{l}\text { Rất an } \\
\text { toàn }\end{array}$ & $\begin{array}{l}\text { Không xảy ra trường hợp mất ổn định về an ninh, } \\
\text { chính trị, trật tự xã hội; không có người bán hàng } \\
\text { rong, ăn xin }\end{array}$ \\
\hline & & $\begin{array}{l}\text { Khá an } \\
\text { toàn }\end{array}$ & $\begin{array}{l}\text { Không xảy ra trường hợp mất ổn định về an ninh, } \\
\text { chính trị, trật tự xã hội; có người bán hàng rong, ăn } \\
\text { xin nhưng không đáng kể }\end{array}$ \\
\hline & & $\begin{array}{l}\text { Trung } \\
\text { bình }\end{array}$ & $\begin{array}{l}\text { Không xảy ra trường hợp mất ổn định về an ninh, } \\
\text { chính trị, trật tự xã hội; có nhiều người bán hàng } \\
\text { rong, ăn xin }\end{array}$ \\
\hline & & $\begin{array}{l}\text { Kém an } \\
\text { toàn }\end{array}$ & $\begin{array}{l}\text { Có những biểu hiện bất ổn định về an ninh, chính trị, } \\
\text { trật tự xã hội: trấn lột, chén ép khách, trộm cắp... }\end{array}$ \\
\hline & Tổng số điểm & & \\
\hline
\end{tabular}

Nguồn: do tác giả tính toán, phân tích 2016

\subsubsection{Cách tính điểm và phân hạng kết quả đánh giá tổng hợp}

Điểm số tương ứng với các cấp đánh giá (tốt, khá, trung bình (TB), kém là 4, 3, 2, 1). Điểm đánh giá một tiêu chí là tích của hệ số và điểm của cấp đánh giá. Điểm đánh giá tổng hợp cho một điểm du lịch được tính bằng tổng số điểm đánh giá của các tiêu chí thành phần. Kết quả đánh giá tổng hợp được phân thành 4 hạng. Khoảng cách điểm giữa các hạng bằng nhau và được tính bằng trung bình cộng giữa điểm cao nhất và điểm thấp nhất trong thang điểm. Dựa vào cách tính điểm và phân hạng kết quả đánh giá tổng hợp ta có bảng điểm đánh giá tổng hợp cao nhất và thấp nhất như sau:

Bảng 3. Điểm đánh giá tổng hợp các tiêu chí điểm du lịch

\begin{tabular}{|c|c|c|c|c|c|c|}
\hline \multirow[b]{2}{*}{ STT } & \multirow[b]{2}{*}{ Tiêu chí } & \multirow[b]{2}{*}{ Hệ số } & \multicolumn{4}{|c|}{ Cấp đánh giá } \\
\hline & & & Tốt & Khá & $\begin{array}{l}\text { Trung } \\
\text { bình }\end{array}$ & Kém \\
\hline 1 & Độ hấp dẫn về cảnh quan du lịch & 3 & 12 & 9 & 6 & 3 \\
\hline 2 & $\begin{array}{l}\text { Mức độ hấp dẫn về văn hoá cộng } \\
\text { đồng }\end{array}$ & 3 & 12 & 9 & 6 & 3 \\
\hline 3 & Vị trí điểm du lịch & 3 & 12 & 9 & 6 & 3 \\
\hline 4 & Thời gian hoạt động du lịch & 3 & 8 & 6 & 4 & 2 \\
\hline 5 & Sức chứa khách du lịch & 2 & 8 & 6 & 4 & 2 \\
\hline 6 & Tính liên kết & 2 & 8 & 6 & 4 & 2 \\
\hline
\end{tabular}




\begin{tabular}{|l|l|c|c|c|c|c|}
\hline 7 & Khả năng tiếp cận điểm du lịch & 2 & 8 & 6 & 4 & 2 \\
\hline 8 & Mức độ bền vững về tự nhiên & 2 & 8 & 6 & 4 & 2 \\
\hline 9 & $\begin{array}{l}\text { Mức độ bền vững về văn hoá cộng } \\
\text { đồng }\end{array}$ & 2 & 8 & 6 & 4 & 2 \\
\hline 10 & Mức độ an toàn về mặt xã hội & 2 & 8 & 6 & 4 & 2 \\
\hline & Tống số điểm & & $\mathbf{9 2}$ & $\mathbf{6 9}$ & $\mathbf{4 6}$ & $\mathbf{2 3}$ \\
\hline
\end{tabular}

Nguồn: do tác giả tính toán 2016

Áp dụng công thức tính điểm ta có $X 0=[X \max -X m i n] / n$ (trong đó: $X 0$ là khoảng cách đều giữa các hạng; $X$ max: Điểm cao nhất $=92, X \min$ : Điểm thấp nhất $=23$, n: số cấp phân hạng = 4). Kết quả: $X 0=13$.

Như vậy: điểm đánh giá tổng hợp về tiềm năng của các điểm du lịch ở cù lao Bạch Đằng sẽ là: [Tốt: có tiềm năng rất lớn, thang điểm từ 75-92; Khá: có tiềm năng lớn, thang điểm từ 58-74; Trung bình: có tiềm năng không lớn, thang điểm từ 41-57; Kém: không có tiềm năng đáng kể, thang điểm từ 23-40].

Bảng 5. Kết quả đánh giá tiềm năng du lịch nông thôn cù lao Bạch Đằng

\begin{tabular}{|c|c|c|c|c|c|c|c|c|c|c|c|c|}
\hline \multirow{2}{*}{ STT } & \multirow{2}{*}{ Điểm du lịch } & \multicolumn{10}{|c|}{ Tiêu chí đánh giá } & \multirow{2}{*}{ Tổng } \\
\hline & & 1 & 2 & 3 & 4 & 5 & 6 & 7 & 8 & 9 & 10 & \\
\hline 1 & Hộ nhà vườn trồng bưởi & 12 & 12 & 9 & 8 & 8 & 6 & 6 & 6 & 6 & 8 & 81 \\
\hline 2 & $\begin{array}{l}\text { Các điểm tín ngưỡng } \\
\text { dân gian }\end{array}$ & 9 & 9 & 9 & 4 & 2 & 6 & 4 & 8 & 8 & 8 & 67 \\
\hline 3 & Sân Golf Mekong & 9 & 12 & 9 & 6 & 4 & 8 & 8 & 8 & 8 & 8 & 80 \\
\hline 4 & Đình Tân Trạch & 6 & 6 & 9 & 4 & 6 & 4 & 4 & 8 & 6 & 8 & 61 \\
\hline 5 & $\begin{array}{l}\text { Các ngôi chùa Bạch } \\
\text { Đằng }\end{array}$ & 6 & 4 & 9 & 6 & 6 & 4 & 6 & 8 & 6 & 8 & 63 \\
\hline 6 & Nhà cổ Đỗ Cao Thứa & 12 & 9 & 9 & 8 & 4 & 4 & 4 & 6 & 8 & 8 & 72 \\
\hline 7 & Các hộ trồng hoa màu & 9 & 9 & 9 & 8 & 4 & 4 & 4 & 6 & 6 & 8 & 67 \\
\hline 8 & Các hộ trồng lúa & 9 & 9 & 9 & 8 & 6 & 4 & 4 & 6 & 6 & 8 & 69 \\
\hline & Tổng số điểm & & & & & & & & & & & \\
\hline
\end{tabular}

Nguồn: do tác giả tính toán 2016

Kết quả đánh giá cho thấy các điểm du lịch nông thôn có tiềm năng rất lớn trong trong động du lịch nới đây bao gồm: hộ nhà vườn trồng bưởi, sân Golf Mekong, nhà cổ Đỗ Cao Thứa và các điểm tiềm năng liên kết trong hoạt động du lịch các hộ trồng lúa, các điểm tín ngưỡng dân gian, các hộ trồng hoa màu... Với các điểm đánh giá có tiềm năng như trên, nhóm nghiên cứu nhận định có thể xây dựng một số mô hình hoạt động du lịch nông thôn kết hợp vườn cây ăn trái Cù lao Bạch Đằng như sau:

\section{(1) Hoạt động tham quan vườn bưởi tại các hộ dân}

Mục đích: Mang đến cho du khách cảm giác thư giãn với bầu không khí trong lành, thoáng mát; du khách được tìm hiểu lịch sử, văn hóa từ cây bưởi, phương thức canh tác của nông hộ Cù lao Bạch Đằng đồng thời thưởng thức trái cây mang hương vị đặc trưng nơi đây do chính tay mình hái và các sản phẩm từ bưởi như: nước uống trái cây, nước ép, mật, rượu... 
Hoạt động của mô hình: HTX phân công cụ thể đưa nhóm khách đến từng vườn. Các chủ vườn sẽ giới thiệu lịch sử, văn hóa và con người của vườn bưởi Cù lao Bạch Đằng, sự tích và các câu chuyện dân gian từ vùng đất này. Bên cạnh đó, hướng dẫn du khách cách hái, trồng và chăm bón... thưởng thức mà không làm tổn hại đến sức sống của cây. Trong chương trình tham quan, du khách có thể yêu cầu chủ vườn cây chế biến các món ăn lấy nguyên liệu từ chính những sản phẩm do người dân trồng trọt, chăn nuôi có được như: gỏi bưởi, chè bưởi, các ẩm liệu về bưởi (như chữa bệnh từ song lá bưởi, gội đầu từ bông bưởi...)

\section{(2) Tham quan làng nghề, các điểm di tích}

Mục đích: Giới thiệu sản phẩm từ nghề thủ công và các di tích, phong tục trên Cù lao Bạch Đằng đến với du khách.

Hoạt động của mô hình: du khách được tìm hiểu lịch sử như: nhà cổ ông Đỗ Cao Thứa là di tích kiến trúc nghệ thuật cấp tỉnh, đình Tân Trạch là di tích văn hóa cấp tỉnh, đình Bình Hưng với các lễ cúng mang bản sắc địa phương như: Lễ Tấn phong, Lễ Kỳ Yên, Lễ Khép Ân; quan sát và tham gia trực tiếp các công đoạn sản xuất.

\section{(3) Du ngoạn trên sông, kênh rạch sông Đồng Nai liên kết vùng}

Mục đích: Khai thác lợi thế sông nước của khu vực, tạo không gian yên tĩnh, êm đềm cho du khách sau những ồn ào náo nhiệt chốn phố phường.

Hoạt động của mô hình: Du khách được du ngoạn bằng thuyền ngắm cảnh. Có thể dừng lại một điểm nào đó để câu cá, sau đó mang lên các nhà chòi, khu vực cắm trại 2 bên bờ để chế biến (nướng cá chẳng hạn). Sau cuộc du thuyền, câu cá đã khá mệt thì được ngã mình dưới vườn cây hóng mát, thưởng thức cá nướng và ăn trái cây tại vườn. Kết thúc hành trình, du khách có thể ghé các khu vực thuyền buôn bán trái cây dọc trên bờ sông Đồng Nai để mua trái cây về làm quà cho người thân.

Địa điểm xây dựng mô hình: Dọc sông Cù lao Bạch Đằng, đoạn sông Đồng Nai chảy qua kết nối với cù lao Phố, cù lao Ba Xê, các cơ sở gốm, (trong đó có cơ sở gốm Phong Sơn), nhà cổ Trần Ngọc Du, đền thờ Nguyễn Hữu Cảnh, Thất phủ cổ miếu (chùa Ông), Đại giác cổ tự, danh thắng núi Bửu Long, Văn miếu Trấn Biên, điểm du lịch sinh thái Năm Huệ làng bưởi Tân Triều, các nhà hàng, quán ăn nằm rải ven sông.

\section{(4) Nghe đòn ca tài tử Nam Bộ}

Mục đích: Bảo tồn, phát huy và giới thiệu đến du khách giá trị văn hóa nghệ thuật dân gian đờn ca tài tử của địa phương.

Hoạt động của mô hình: Du khách trở về khu vực lưu trú sau 1 ngày tham quan, nghe các nghệ nhân đờn ca tài tử biểu diễn và cùng tham gia diễn xuất, tìm hiểu nhiều thông tin liên quan đến đờn ca tài tử.

Địa điểm xây dựng mô hình: Nhà hàng Bạch Đằng

\section{(5) Đánh gofl - hoạt động dân dã trên cù lao}

Mục đích: giúp du khách hiểu hơn về môn giải trí đánh golf và giới thiệu đến $d u$ khách giá trị văn hóa dân gian của địa phương. 
Hoạt động của mô hình: Du khách biểu diễn đánh gofl và cùng tham gia tìm hiểu địa phương thông qua các phương tiện cổ như: xe ngựa kéo chạy quanh đường làng, ghé vào những điểm du lịch điển hình của cù lao Bạch Đằng.

\subsection{5. Đánh giá chung}

Thế mạnh: Các yếu tố về tự nhiên đa dạng, mang đậm tính chất của đồng bằng điền trũng với hệ thống sông ngòi dày đặc, khí hậu ôn hòa, đồng bằng phù sa màu mỡ, cho phép xã có thể phát triển một nền nông thôn đa dạng với nhiều loại cây đặc trưng và hệ thống vườn cây ăn quả, từ đó có thể phát triển loại hình du lịch tham quan, học tập;

Hệ thống các giá trị nhân văn phong phú, bao gồm hệ thống các giá trị di tích lịch sử, làng nghề và các đối tượng liên quan đến dân tộc học..., kết hợp với các tiềm năng về tự nhiên, tạo cơ sở cho việc xây dựng và phát triển các loại hình du lịch nông thôn khác nhau như: du lịch tham quan, sinh thái vườn trái cây, tìm hiểu kiến trúc cổ;

Bạch Đằng có nhiều thế mạnh nông thôn, đặc biệt là trồng bưởi và sản xuất lúa. Cơ cấu của sản xuất nông thôn ngày càng đa dạng, nhiều sản phẩm nông thôn được ứng dụng khoa học công nghệ tạo ra sản lượng và chất lượng cao. Loại hình HTX ngày càng được mở rộng. Xã Bạch Đằng trở thành điểm đến hấp dẫn của các hộ sản xuất nông thôn trong vùng và cả nước. Họ đến để học hỏi, tiếp thu những kinh nghiệm trong sản xuất nông thôn của xã, qua đó góp phần thúc đẩy hình thức du lịch nông thôn phát triển.

Hạn chế: Nguồn nhân lực dành cho phát triển du lịch nông thôn nhìn chung còn thiếu về số lượng và hạn chế về chất lượng. Người nông dân chưa được đào tạo về du lịch và các kĩ năng cơ bản về kinh doanh tổ chức du lịch;

Các điều kiện về hệ thống các tuyến điểm liên kết, quảng bá hình ảnh còn chưa đáp ứng được các yêu cầu của phát triển du lịch. Hệ thống các tuyến điểm liên kết, đặc biệt là cơ sở lưu trú, tham quan còn khá khiêm tốn. Các hình thức quảng bá còn hạn chế;

Việc đầu tư cho phát triển du lịch nông thôn còn mới ở dạng thử nghiệm. Việc quy hoạch và định hướng tổ chức phát triển du lịch nông thôn còn chưa được thực hiện để phát huy các thế mạnh sã̃n có của du lịch nông thôn tại tỉnh.

2.2.6. Định hướng khai thác phát triển du lịch nông thôn xã Bạch Đằng theo hướng sinh thái bền vững:

Xác định các thế mạnh trọng tâm của xã về du lịch nông thôn, từ đó đầu tư có trọng điểm nhằm tạo nên hiệu quả đối với phát triển du lịch nông thôn theo hướng sinh thái bền vững;

Nâng cao việc đào tạo nguồn nhân lực địa phương cho phát triển du lịch nông thôn dựa trên việc mở rộng các loại hình đào tạo, mở các lớp tập huấn ngắn hạn, kết hợp với việc học hỏi và phổ biến kinh nghiệm về phát triển du lịch nông thôn trong nước và thế giới cho các nông hộ, các thành viên HTX làm du lịch;

Nâng cao chất lượng và phát triển đa dạng hơn nữa các sản phẩm du lịch nông thôn. Kết hợp các loại hình du lịch gắn liền với hệ sinh thái sông nước, đồng quê và văn hóa, tập tục địa phương. Xây dựng các sản phẩm du lịch nông thôn đặc thù, tạo lợi thế so sánh của xã Bạch Đằng so với các địa phương khác trong vùng; 
Tiếp tục hoàn thiện cơ chế và hệ thống chính sách cũng như các ưu đãi nhằm thu hút hơn nữa việc đầu tư vào phát triển du lịch nông thôn. Phát triển hệ thống liên kết tuyến điểm giữa công ty du lịch và nhà vườn, đẩy mạnh việc quảng bá xúc tiến du lịch nông thôn thông qua các sản phẩm nông nghiệp để thu hút khách đến với nơi đây.

Phát triển du lịch du lịch nông thôn theo hướng phát triển sinh thái bền vững sẽ đáp đứng được các yêu cầu của PTBV dựa trên 19 tiêu chí Nông thôn mới và 47 tiêu chí phát triển dịch vụ lưu trú của Bộ KHCN Ban hành, theo đó quan điểm lấy DLST là định hướng trong Chính sách Nhà nước như sau: Du lịch tự nhiên gắn liền với vùng quê nông thông sông nước, cây ăn trái, mang tính giải trí, xả tress; Du lịch văn hoá, quan tâm tới văn hoá, lịch sử và di tích của xã; Du lịch sinh thái quan tâm tới việc bảo vệ nguồn lợi tự nhiên, cũng như phúc lợi, giá trị văn hoá của người dân địa phương; Du lịch làng xã, trong đó du khách chia sẻ với cuộc sống làng xã và dân làng được hưởng các lợi ích kinh tế do các hoạt động du lịch mang lại; Du lịch nông nghiệp trong đó khách du lịch tham quan và tham gia vào các hoạt động nông nghiệp truyền thống, không phá hoại, hay làm giảm năng suất của địa phương.

\section{Kết luận}

Xã Bạch Đằng có nhiều tiềm năng to lớn để phát triển du lịch nông thôn và thực tế bước đầu khảo sát các công ty lữ hành đã áp dụng một số chương trình du lịch cho du khách trong và và ngoài nước cho thấy tác động to lớn của du lịch nông thôn đối với đời sống của người nông dân và kinh tế xã hội nơi đây. Để tiếp tục biến tiềm năng thành các nguồn lực cơ bản, xã Bạch Đằng nên xây dựng chiến lược và quy hoạch cụ thể trong du lịch, phát triển nguồn nhân lực có chất lượng, áp dụng các hình thức sản xuất tiên tiến nông nghiệp sạch theo các tiêu chuẩn quốc tế, đa dạng hóa các kênh quảng bá về các sản phẩm du lịch nông thôn. Các kết quả đánh giá trên đây bước đầu sẽ góp phần giúp các cấp chính quyền địa phương và các sở ban ngành ở tỉnh Bình dương trong việc xây dựng quy hoạch chi tiết địa phương, chiến lược phát triển du lịch nông thôn theo định hướng sinh thái bền vững.

\section{Chú thích:}

(1) Phòng Kinh tế thị xã Tân Uyên phối hợp với Sở Nông nghiệp và Phát triển nông thôn tỉnh Bình Dương tổ chức triển khai Quyết định số 45/2012/QĐ-UBND ngày 16/10/2012 của UBND tỉnh Bình Dương ban hành quy định một số chính sách hỗ trợ giữ và phát triển vườn cây ăn quả đặc sản tỉnh Bình Dương giai đoạn 2013 - 2016 đến cán bộ công chức; các chủ trang trại và các hộ nông dân trên địa bàn xã Bạch Đằng.

(2) Thực hiện Quyết định số 45/2012/QĐ-UBND ngày 16/10/2012 của UBND tỉnh Bình Dương ban hành quy định một số chính sách hỗ trợ giữ và phát triển vườn cây ăn quả đặc sản tỉnh Bình Dương giai đoạn 2013 - 2016.

(3) Bưởi Bạch Đằng được Cục SHTT cấp Giấy chứng nhận đăng ký nhãn hiệu tập thể số 166282 ngày $23 / 6 / 2011$ cho $5 / 9$ loại bưởi nơi đây đang được trồng và phát triển bao gồm bưởi đường da láng (bưởi đường núm), bưởi đường lá cam, bưởi ổi, bưởi thanh và bưởi da xanh. Nhãn hiệu Bưởi Bạch Đằng do Hội nông dân xã Bạch Đằng (huyện Tân Uyên, tỉnh Bình Dương) sở hữu, có quy trình trồng khép kín và cho ra những trái bưởi ngon, ngọt 
(4) Truy cập thông tin tại: http://baobinhduong.vn/to-hop-tac-buoi-bach-dang-duabuoi-di-xa-a104701.html.

(5) Thương hiệu Bưởi Bạch Đằng đã được đăng ký tại Cục Sở hữu trí tuệ và được nhà nước bảo hộ độc quyền theo chứng nhận đăng ký nhãn hiệu tập thể số 166282 ngày 23/6/2011 cho 5 loại bưởi đang được trồng và phát triển bao gồm bưởi đường da láng (bưởi đường núm), bưởi đường lá cam, bưởi ổi, bưởi thanh và bưởi da xanh.

\section{Tài liệu tham khảo}

1. Chi cục Thống kê tỉnh Bình Dương $(2013,2014)$, Niên giám thống kê Bạch Đằng.

2. Nguyễn Minh Tuệ và nnk (2010), Địa lí du lịch Việt Nam, Nxb Giáo dục, Hà Nội.

3. Sở Văn hóa, Thể thao và Du lịch Bình Dương (2012), Quy hoạch phát triển ngành du lịch Bạch Đằng giai đoạn đến 2020, định hướng 2030.

4. Ban Quản lý xây dựng nông thôn mới xã Bạch Đằng, Báo cáo sơ kết 3 năm thực hiện chương trình mục tiêu quốc gia xây dựng nông thôn mới xã Bạch Đằng 2011-2013.

5. Brian J. Schilling, Lucas J. Marxen, Helen H. Heinrich, Fran J. A. Brooks (2006), The Opportunity for Agritourism Development in New Jersey, Food Policy Institute, pp.7-28.

6. Christine Tew (2010), Importance of Agritourism for agripreneur goal accomplishment, Thesis of Faculty of the Gradu ate School University of Missouri, pp.5-20.

7. Ngo-Hoang, D. L. (2014). Coconut planting in Ben Tre is a culture that responds to the natural environment and responds to climate change from a cultural ecological perspective. Available at SSRN 3456708.

8. Minh, D. Đ., \& Long, N. H. Đ. (2010). Bước đầu xây dựng sản phẩm du lịch đặc thù cho các tỉnh phía Nam tỉnh Lâm Đồng. Đề tài khoa học cấp cơ sở, Trường Đại học Khoa học xã hội và nhân văn TP. Hồ Chí Minh, 170tr.

9. Long, N. H. Đ. (2016). Khai thác sản phẩm du lịch đảo Lý Sơn trong bối cảnh hội nhập tiếp cận từ địa văn hóa. Tạp chí Phát triển Khoa học và Công nghệ, 19(5X), 83-94.

10. Ngo-Hoang, D. L. (2014). Evaluate The Effectiveness Of The AgricultureForestry-Fishery Combined Model On Hon Tre Island Commune, Kien Giang.

11. Sở Văn hóa,Thể thao và Du lịch tỉnh Bình Dương-Viện Nghiên cứu phát triển du lịch, Báo cáo Quy hoạch phát triển du lịch Bình Dương đến năm 2020 tầm nhìn đến 2030.

12. UBND xã Bạch Đằng, Báo cáo tình hình kinh tế-văn hóa xã hội-quốc phòng an ninh 2014 và phương hướng nhiệm vụ năm 2015.

13. UBND Bình Dương (2010), Địa chí Bình Dương, Hà Nội, Nxb. Chính trị quốc gia.

14. Website UBND tỉnh Bình Dương: www.binhduong.gov.vn

15. Website về Atlas tỉnh Bình Dương: www.atlas.binhduong.gov.vn 


\section{ĐÁNH GIÁ TIỀM NĂNG PHÁT TRIẺN DU LỊCH NÔNG THÔN TẠI XÃ BACH ĐÀ̀NG, THI! XÃ TÂN UYÊN, TỈNH BİNH DƯO'NG}

\section{Tóm tắt}

Du lịch nông thôn là một hình thức du lịch đang phổ biến ở các vùng lãnh thổ của nước ta, nơi có lợi thế về nông nghiệp. Việc phát triển du lịch nông thôn đã và đang đem lại nhiều lợi ích, cơ hội cho phát triển nông nghiệp cũng như đa dạng hóa các loại hình dịch vụ du lịch và cải thiện đời sống dân sinh cho bà con nông dân ở các vùng nông thôn. Bài báo tập trung đánh giá tổng hợp về tiềm năng phát triển du lịch nông thôn ở xã Bạch Đằng. Kết quả đánh giá cho thấy, xã Bạch Đằng có nhiều lợi thế về tự nhiên, nhân văn và các chính sách đầu tư cho việc phát triển du lịch nông thôn ở nơ đây. Tuy nhiên, còn một số hạn chế về nguồn nhân lực và sản phẩm du lịch địa phương chưa đáp ứng yêu cầu phát triển loại hình này.

Từ khóa: đánh giá tiềm năng, du lịch nông thôn, xã Bạch Đằng, sản phẩm du lịch 